\title{
Isolation of Antisnake Venom Agents from Azadirachta Indica (A. Juss) Leaf Extracts
}

\section{Ibrahim Sani (Corresponding Author)}

Department of Biochemistry, Kebbi State University of Science and Technology, Aliero, Nigeria Email: isani76@gmail.com

\section{Rabi'u Aliyu Umar}

Department of Biochemistry, Usmanu Danfodiyo University, Sokoto, Nigeria

\section{Sanusi Wara Hassan}

Department of Biochemistry, Usmanu Danfodiyo University, Sokoto, Nigeria

\section{Umar Zaki Faruq}

Department of Pure and Applied Chemistry, Usmanu Danfodiyo University, Sokoto, Nigeria

\section{Fatima Bello}

Amrita Vishwa Vidyapeetham, Amritanagar, Ettimadai, Coimbatore, Tamil Nadu 641112
Article History

Received: January 8, 2020

Revised: February 2, 2020

Accepted: February 11, 2020

Published: February 15, 2020

Copyright (C) 2020 ARPG \& Author

This work is licensed under the Creative Commons Attribution International

\section{(c) (1) CC BY: Creative}

Commons Attribution License 4.0

\begin{abstract}
Phytochemicals with protein binding properties, active against snake envenomation such as flavonoids, polyphenols, saponins, tannins, terpenoids, xanthenes, quinonoids, steroids and alkaloids bind to toxic venom proteins thereby inactivating them. This research was aimed at isolating antisnake venom agents from Azadirachta indica leaf extracts using activity-guided isolation protocols. A. indica leaf was collected, authenticated and extracted using methanol followed by solvent-fractionation using hexane and ethylacetate. These fractions were further separated using column and thin-layer chromatography. The pooled chromatographic fractions were screened for the antivenom activity using Naja nigricollis venom phospholipase A2 (NVPLA2) inhibition assay and albino rat models. Polyvalent serum-based antivenin was used as standard. The column chromatography of the A. indica leaf hexane and ethylacetate extracts yielded sixty (60) and sixty nine (69) fractions. Based on similarities on the TLC profiles, fractions were pooled. Eleven (11) pooled hexane fractions (PHFs) and fourteen (14) pooled ethylacetate fractions (PEFs) were obtained. After antivenom activity screening, pooled hexane fraction 3 (PHF3) and pooled ethylacetate fraction 1B (PEF1B) from the hexane and ethylacetate fractions respectively protected envenomed albino rats from death at a dose of $20 \mathrm{mg} / \mathrm{kg} \mathrm{b.w}$. against $0.8 \mathrm{mg} / \mathrm{kg}$ b.w. of $N$. nigricollis venom. Hence, these findings suggest that the isolated active compounds can serve as leads for the development of safe, readily available and affordable plant-based antivenoms.
\end{abstract}

Keywords: Azadirachta indica; Phytochemicals; Snake Venom; Antivenom; PHF3; PEF1B.

\section{Introduction}

Snakebite is a neglected public health problem in most of the countries in Africa. Rural populations are frequent victims as they go about their daily food production and animal rearing activities and as they reside in the comfort of their homes [1]. Unfortunately, many of these snakebite cases go unreported and thus do not appear in official epidemiological statistics. Health workers often have little or no formal training in the management of snakebite, and appropriate antivenom is rarely available. However, antivenins also have some disadvantages, thus limiting their efficient use. For example, Production of antivenins is a painstaking, resource-intensive and time-consuming process [2]. Another important issue with the conventional antivenins is the knowledge of which species of snakes inflicted the bite. If antivenin for a wrong species is administered, it may not be effective. The general problem with these conventional antivenins is the allergic effect of animal serum to a number of victims. The allergy can be so severe as to cause death, otherwise must be treated separately [3]. Additionally, antivenins do not neutralize the local tissue damage [4].

Herbal constituents have been reported to neutralize toxic venom constituents through several mechanisms [5]. They can bind to toxic venom proteins thereby inactivating them [6]. They could also competitively block the target receptors [7]. Flavonoids like myricetin, quercetin and amenthoflavone isolated from Davilla elliptica and Byrsonima crassa leaves have antihaemorrhagic activity against venom of Bothrops jararaca [8].

Sunitha, et al. [9], investigated the molecular mechanism by which polyphenols from plant extracts interact with $\alpha$-cobratoxin, a neurotoxin from the venom of certain Naja snakes, which causes paralysis by preventing the binding of acetylcholine to the muscle-type nicotinic acetylcholine receptor (nAChR). They evaluated the interaction between this toxin and some phenolic compounds, such as tannic acid, digallic acid, procyanidin dimer and procyanidin trimer, present in the extracts of some selected plants. Molecular modeling revealed the formation of 
hydrogen bonding between hydroxyl groups of tannins and amino acid residues surrounding their binding site to $\alpha$ cobratoxin.

Soares, et al. [10], suggested that plant extracts have compounds that bind to divalent metal ions, which are required for some enzymatic activities. Presence of proper metal ion coordination is a pre-requisite for the hydrolytic activities of phospholipase A2 (PLA2) and metalloproteinases [11]; hence, any metabolite that can weaken the enzyme-metal ion interaction would result in the inactivation of the hydrolytic activity [6].

Snake venom proteinases majorly affect haemostasis and cause systemic haemorrhage [12]. The mechanism of inactivation of these proteinases by plant extracts could be by chelating property of phenolic components present in plant extract [13]. Phenolic compounds form hydrogen bonds and strongly bind to the histidine residues present in $\mathrm{Zn}^{2+}$ binding motifs of metalloproteinases, resulting in decrease in the hydrolytic activity of the enzyme [14].

Snake venoms are rich in PLA2s which are $\mathrm{Ca}^{2+}$ dependent and hydrolyze 2-acyl ester bonds of membrane glycerophospholipids producing free fatty acids and lysophospholipids [15] which are key components of inflammatory process [11]. The mechanisms by which plants can act against the snake venom PLA2 have been extensively studied [5]. Among them, the phytochemicals as catequines, flavones, anthocyanines and condensed tannins were related in their abilities in the chelation of the $\mathrm{Ca}^{2+}$ required for the catalytic activity of snake venom PLA2 [6].

Phenolic compounds can form complex with metal ions only when they have suitably oriented functional groups in their structure [13]. The presence of 3'-4' and/or 7-8 o-dihydroxyphenyl (catechol) groups or 5-OH and/or 3-OH in conjugation with a $\mathrm{C} 4$ keto group in phenolic compounds structure is important for metal ions binding [16]. The chelating activity increases when galloyl moiety $\left(3^{\prime}, 4^{\prime}, 5^{\prime}-\mathrm{OH}\right.$ trihydroxybenzene) is present in the molecules of phenolic compounds [16, 17]. When chemical structure of tannins is considered, it could be presumed that condensed tannins, which are catechin polymers, bind metal ions mainly to catechol groups, whereas hydrolysable tannins (derivatives of gallic acid) to galloyl groups [18].

\section{Materials and Methods}

\subsection{Study Area}

The research was conducted between April, 2018 to February, 2019 in Biochemistry Research Labouratory, Department of Biochemistry, Faculty of Life Sciences, Kebbi State University of Science and Technology, Aliero, Nigeria.

\subsection{Experimental Animals}

Adult Wister albino rats of both sexes aged $4-5$ months and weighing between $150-280 \mathrm{~g}$ were used for the experiments. They were purchased from National Veterinary Research Institute, Vom, Nigeria and kept under standard laboratory conditions $\left(22-24^{\circ} \mathrm{C} ; 12: 12 \mathrm{~h}\right.$ dark/light cycle). The animals were allowed free access to both food (commercial rodents pellets) and water ad libitum [19], they were allowed to acclimatize for 2 weeks. Weight of each rat was taken before the commencement of the experiment. All animal experiments were conducted in accordance with the guidelines for the use and care of experimental animals [20].

\subsection{Standard Snake Venom Antiserum (Antivenin)}

The lyophilized polyvalent snake venom antiserum (Batch No.: 01AS83659, Man. Date: March, 2018, Exp. Date: February, 2021) was used as standard to compare with the efficacy of the plant extract. It was produced by a standard pharmaceutical company (VINS Bioproducts Limited, Andhra Pradesh, India).

\subsection{Naja Nigricollis}

The snake specie (Naja nigricollis) used was captured and housed in a wooden cage with the help of a snake charmer. After collection, it was duly identified by a zoologist. Its venom was milked and used for the experiments.

\subsection{Milking of Venom}

The venom was collected at $5.30 \mathrm{pm}$, in a low light condition at ambient temperature according to the method of Goswami, et al. [21] by using a short-acting general anesthesia; halothane (Piramal Healthcare Limited, U.K.). The glands below the eyes of the snake were compressed to release the stored venom into a clean and sterilized container.

\subsection{Preparation of Venom}

After milking, the venom was lyophilized using a freeze-dryer (Millrock Technology, USA) and kept inside a refrigerator (HR135A, Haier-Thermocool, Lagos, Nigeria) in a light resistant and air-tight container. Before use, the lyophilized venom was reconstituted in $0.9 \%$ saline (regarded as the venom) and kept at $4^{\circ} \mathrm{C}$. The venom concentration was expressed in terms of dry weight $(\mathrm{mg} / \mathrm{ml})[22]$.

\subsection{Collection and Authentication of the Plant Material}

Azadirachta indica leaf was collected within Aliero town, Kebbi State, Nigeria. It was authenticated at the herbarium of the Department of Plant Science and Biotechnology, Kebbi State University of Science and Technology, Aliero, and voucher specimen was deposited there; VN:083. 


\subsection{Preparation of Crude $A$. indica Leaf Methanol Extract}

The extract was prepared according to the method of Dupont, et al. [23]. The collected leaves were washed with clean water and air-dried under shade, pulverized using pestle and mortar. One kilogramme $(1 \mathrm{~kg})$ of the powdered leaf was measured and soaked in $2.5 \mathrm{~L}$ of $95 \%$ methanol. The mixture was then kept at room temperature for $24 \mathrm{~h}$ and filtered twice; initially with a muslin cloth and later with a Whatman filter paper No.1. The filtrate was evaporated to dryness at $45^{\circ} \mathrm{C}$ using rotary evaporator. The residue was further fractionated.

\subsection{Solvent-Fractionation of the Crude $A$. indica Leaf Methanol Extract}

The crude methanol extract of the $A$. indica leaf was fractionated by liquid-liquid extraction using $\mathrm{n}$-hexane and ethylacetate in increasing order of polarity. Two hundred grammes $(200 \mathrm{~g})$ of the dried methanol extract were reconstituted in $400 \mathrm{ml}$ of distilled water in a 1 liter separating funnel. This was then partitioned sequentially with equal volume of $n$-hexane, and ethylacetate to yield the n-hexane and ethylacetate fractions. The fractions were concentrated to dryness and the residues were used for the chromatographic separations.

\subsection{Chromatographic Separation of Hexane and Ethylacetate Fractions \\ 2.10.1. Column Chromatography}

The components of each of the two (2) fractions (hexane and ethylacetate) were separated using column and thin layer chromatographic techniques on silica gel. The silica gel (100-200 mesh) $(150 \mathrm{~g})$ was mixed with $n$-hexane and the wet silica gel was loaded into the column using additional $n$-hexane. The dried form of the hexane or the ethylacetate fraction $(3 \mathrm{~g})$ was then added into the packed column. For the hexane extract, the column was eluted with hexane:ethylacetate (100:0, 98:02, 95:05, 90:10, 80:20, 70:30, 60:40, 50:50, 40:60, 30:70, 20:80, 10:90 and $0: 100 \% \mathrm{v} / \mathrm{v}, 100 \mathrm{ml}$ each). For the ethylacetate extract, the column was eluted with hexane:ethylacetate (100:0, 98:02, 95:05, 90:10, 80:20, 70:30, 60:40, 50:50, 40:60, 30:70, 20:80, 10:90 and 0:100 \% v/v, $100 \mathrm{ml}$ each), followed by ethylacetate:methanol (98:02, 95:05, 90:10, 80:20, 70:30, 60:40, 50:50, 40:60, 30:70, 20:80, 10:90 and 0:100 $\% \mathrm{v} / \mathrm{v}, 100 \mathrm{ml}$ each). The eluted fractions were collected into small sample bottles $(20 \mathrm{ml}$ each). The fractions were allowed to dry, pooled and then tested for the antisnake venom activity (in vitro and in vivo) after studying their TLC profiles.

\subsubsection{Thin Layer Chromatography (TLC) of the Eluted Fractions}

The dried column chromatographic fractions obtained were reconstituted in either hexane or ethylacetate and spotted on TLC plates, then developed with hexane:ethylacetate (70:30) solvent system. The developed plates were allowed to dry and detection of compounds was aided by dipping the plates in vanillin reagent $(1 \mathrm{~g}$ vanillin powder in $94 \mathrm{ml}$ ethanol and $5 \mathrm{ml}$ conc. $\mathrm{H}_{2} \mathrm{SO}_{4}$ ). The plates were heated at $100{ }^{\circ} \mathrm{C}$ for $3-7$ minutes for optimal colour development.

\subsection{NVPLA2 Inhibition Effect of the Pooled Chromatographic Fractions}

The $N$. nigricollis venom phospholipase $\mathrm{A}_{2}$ activity was determined acidimetrically using the method of Tan and Tan [24]. Briefly, a lecithin suspension was prepared with $1 \%$ lecithin, $18 \mathrm{mM}$ calcium chloride and $8.1 \mathrm{mM}$ sodium deoxycholate in equal proportion. The $\mathrm{pH}$ of the suspension was adjusted to 8.0 with $1 \mathrm{M}$ sodium hydroxide, and stirred for 10 minutes to ensure homogenous mixing. An amount of $0.1 \mathrm{ml}$ of venom solution was added to $15 \mathrm{ml}$ of egg yolk suspension to initiate the hydrolysis. The initial decrease in $\mathrm{pH}$ was measured. A decrease of $1 \mathrm{pH}$ unit corresponded to $133 \mu$ mole of fatty acid released. Enzyme activity was expressed as $\mu$ mole of fatty acid released per minute [25]. For the inhibition studies, venom was pre-incubated with a pooled fraction for 30 minutes at $37^{\circ} \mathrm{C}$.

$$
\begin{aligned}
& \text { Enzyme Activity }(\mu \text { mole FA } / \text { min. })=\frac{\mu \text { mole of FA released }}{\text { Time taken in minutes }} \\
& \text { Where: FA = Fatty acid } \\
& \% \text { Activity }=\frac{\text { Enzyme Activity of the test sample }}{\text { Enzyme Actviity of the venom control }} \times 100
\end{aligned}
$$

\subsection{In Vivo Antivenom Activity Screening of the most Active Pooled Fractions}

Twenty five (25) Albino rats were randomly distributed into five (5) groups of five (5) rats each as follows:

Group 1: received $1 \%$ aqueous solution of Tween- 80 orally (p.o.) and served as normal control. control.

Group 2: injected intraperitoneally (i.p.) only with $0.8 \mathrm{mg} / \mathrm{kg}$ b.w. of the snake venom and served as negative

Group 3: injected (i.p.) with $0.8 \mathrm{mg} / \mathrm{kg}$ b.w. of the snake venom, then after $30 \mathrm{~min}$, they were administered intravenously $(i . v$. ) with the standard conventional serum-based antivenin at a dose of $1 \mathrm{ml} / 0.6 \mathrm{mg}$ venom and served as positive control.

Group 4 and 5: served as treatment groups, they were injected (i.p.) with $0.8 \mathrm{mg} / \mathrm{kg}$ b.w. of the snake venom, then after $30 \mathrm{~min}$, they were treated orally with $20 \mathrm{mg} / \mathrm{kg} \mathrm{b}$.w. of the pooled hexane fraction 3 (PHF3) and pooled ethylacetate fraction 1 (PEF1) respectively.

All the groups received same volume of preparations $(0.2 \mathrm{ml})$. In all the groups, the survival time and number of animals survived were recorded for $24 \mathrm{~h}$. 


\subsection{Data Analysis}

Some of the data generated from the study are presented as mean \pm SEM and subjected to one way analysis of variance (ANOVA) and statistical difference between the means were separated using New Duncan's Multiple Range Test at $\mathrm{P}<0.05$ with the aid of a statistical package (IBM SPSS Statistics 20).

\section{Results}

The column chromatography of the A. indica leaf hexane and ethylacetate fractions yielded sixty (60) and sixty nine (69) sub-fractions. Based on similarities on the TLC profiles, the sub-fractions were pooled together. Eleven (11) pooled hexane fractions (PHFs) and fourteen (14) pooled ethylacetate fractions (PEFs) were obtained.

Tables 1 and 2 present the inhibitory effects of the PHFs and PEFs against the activity of $N$. nigricollis venom phospholipase A2 (NVPLA2) respectively. Among the Pooled Hexane Fractions, PHF3 produced the highest inhibition effect of $86.6 \%$ (Table 1), which is even more than that of the standard antivenin with inhibition effect of $72.9 \%$. The crude hexane extract (HE) was able to inhibit the activity of the venom enzyme by $68.5 \%$. For the PEFs, PEF1 indicated highest percentage inhibition of 79.3\% (Table 2). This was also higher than that of the standard antivenin with $72.9 \%$. The crude ethylacetate extract (EAE) showed an inhibitory effect of $51.0 \%$ on the NVPLA2 (Table 2). Hence, among the PHFs and PEFs, PHF3 and PEF1 were observed to be the most active pooled fractions respectively. These pooled fractions (PHF3 and PEF1) were selected for the in vivo analysis.

At the administered dose of $0.8 \mathrm{mg} / \mathrm{kg}$ b.w. of the venom, the screened pooled fractions (PHF3 and PEF1) were able to protect the envenomed rats from death (Table 3). The mean survival time (MST) recorded for each of the PHF3 and PEF1 was $24.00 \pm 0.00 \mathrm{~h}$, which is significantly $(\mathrm{P}<0.05)$ different from that of the venom control with MST of $0.81 \pm 0.23 \mathrm{~h}$ (Table 3).

It was observed that, PHF3 produced a single band on TLC indicating that, it is a single compound fraction. Another TLC verified the homogeneity of the PHF3 by producing a single band with $R f$ value of 0.94 . The compound PHF3 weighed $63.2 \mathrm{mg}$.

For the PEF1, two (2) bands were observed on the TLC signifying a mixture of two (2) compounds. Hence, PEF1 was further fractionated using another column chromatography and yielded PEF1A and PEF1B sub-fractions.

Pooled Ethylacetate Fraction 1A (PEF1A) and Pooled Ethylacetate Fraction 1B (PEF1B) were subjected to another in vitro and in vivo analysis. For the in vitro analysis, the percentage inhibitory effect of the PEF1A and PEF1B on the activity of NVPLA2 was found to be $23.9 \%$ and $89.8 \%$ respectively (Table 4). The in vivo analysis revealed that PEF1B protected the envenomed rats from death with mean survival time of $24.00 \pm 0.00 \mathrm{~h}$, while all the envenomed rats treated with PEF1A could not survive (Table 4). Hence, PEF1B was the most active and was a pure compound weighing $34.6 \mathrm{mg}$ with an $R f$ value of 0.89 .

Table-1. Inhibition of Snake Venom Phospholipase $\mathrm{A}_{2}$ by Pooled Hexane Fractions (PHFs) of A. indica Leaf

\begin{tabular}{|c|c|c|c|c|c|c|c|c|c|c|c|c|c|c|}
\hline Parameter & Venom & $\begin{array}{l}\mathrm{V}+ \\
\mathrm{A}\end{array}$ & $\begin{array}{l}V+ \\
\text { PHFl }\end{array}$ & $\begin{array}{l}V+ \\
\text { PHF2 }\end{array}$ & $\begin{array}{l}++ \\
\text { PHF3 }\end{array}$ & $\begin{array}{l}V+ \\
\text { PHF4 }\end{array}$ & $\begin{array}{l}\text { V + } \\
\text { PHF5 }\end{array}$ & $\begin{array}{l}\begin{array}{l}\text { V + } \\
\text { PHF6 }\end{array} \\
\end{array}$ & $\begin{array}{l}V+ \\
\text { PHF7 }\end{array}$ & $\begin{array}{l}\text { V + } \\
\text { PHF8 }\end{array}$ & 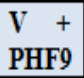 & $\begin{array}{lr}\mathrm{V}+ \\
\text { PHF10 }\end{array}$ & $\begin{array}{lr} & + \\
\text { PHFll }\end{array}$ & $\begin{array}{l}\text { V + } \\
\text { PHE }\end{array}$ \\
\hline $\begin{array}{l}\text { Enzyme } \\
\text { Activity } \\
\text { ( } \mu \text { mole } \\
\text { FA/min) }\end{array}$ & 3.43 & 0.93 & 2.04 & 1.39 & 0.46 & 1.59 & 1.65 & 1.42 & 2.04 & 2.44 & 1.94 & 1.91 & 2.73 & 1.08 \\
\hline $\begin{array}{l}\text { Enzyme } \\
\text { Activity (\%) }\end{array}$ & 100.0 & 27.1 & 59.5 & 40.5 & 13.4 & 46.4 & 48.1 & 41.4 & 59.5 & 71.1 & 56.6 & 55.7 & 79.6 & 31.5 \\
\hline $\begin{array}{l}\text { Enzyme } \\
\text { Inhibition } \\
(\%)\end{array}$ & 0.0 & 72.9 & 40.5 & 59.5 & 86.6 & 53.6 & 51.9 & 58.6 & 40.5 & 28.9 & 43.4 & 44.3 & 20.4 & 68.5 \\
\hline
\end{tabular}

Table-2. Inhibition of Snake Venom Phospholipase $\mathrm{A}_{2}$ by Pooled Ethylacetate Fractions (PEFs) of $A$. indica Leaf

\begin{tabular}{|c|c|c|c|c|c|c|c|c|c|c|c|c|c|c|c|c|c|}
\hline Parameter & Venom & $\begin{array}{l}\mathrm{V}+ \\
\mathrm{A}\end{array}$ & $\begin{array}{l}\mathrm{V}+ \\
\text { PEFl }\end{array}$ & $\begin{array}{l}\mathrm{V}+ \\
\text { PEF2 }\end{array}$ & $\begin{array}{l}\mathrm{V}+ \\
\text { PEF3 }\end{array}$ & $\begin{array}{l}\mathrm{V}+ \\
\text { PEF4 }\end{array}$ & $\begin{array}{l}\mathrm{V}+ \\
\text { PEF5 }\end{array}$ & $\begin{array}{l}\mathrm{V}+ \\
\text { PEF6 }\end{array}$ & $\begin{array}{l}\text { V+ } \\
\text { PEF7 }\end{array}$ & $\begin{array}{l}\mathrm{V}+ \\
\text { PEF8 }\end{array}$ & $\begin{array}{l}\mathrm{V}+ \\
\text { PEF9 }\end{array}$ & \begin{tabular}{|l}
$V+$ \\
PEF \\
10 \\
\end{tabular} & $\begin{array}{l}\mathrm{V}+ \\
\text { PEF } \\
11 \\
\end{array}$ & $\begin{array}{l}\mathrm{V}+ \\
\text { PEF } \\
12 \\
\end{array}$ & $\begin{array}{l}\mathrm{V}+ \\
\text { PEF } \\
13 \\
\end{array}$ & $\begin{array}{l}\mathrm{V}+ \\
\text { PEF } \\
14 \\
\end{array}$ & $\begin{array}{l}\mathrm{V}+ \\
\mathrm{CEAE}\end{array}$ \\
\hline $\begin{array}{l}\text { Enzyme } \\
\text { Activity } \\
\text { ( } \mu \text { mole } \\
\text { FA/min) }\end{array}$ & 3.43 & 0.93 & 0.71 & 1.66 & 1.84 & 2.51 & 2.15 & 2.22 & 2.84 & 1.94 & 2.94 & 3.02 & 2.01 & 3.22 & 2.90 & 3.34 & 1.68 \\
\hline $\begin{array}{l}\text { Enzyme } \\
\text { Activity } \\
(\%)\end{array}$ & 100.0 & 27.1 & 20.7 & 48.4 & 53.6 & 73.2 & 62.7 & 64.7 & 82.8 & 56.6 & 85.7 & 88.0 & 58.6 & 93.9 & 84.5 & 97.4 & 49.0 \\
\hline $\begin{array}{l}\text { Enzyme } \\
\text { Inhibition } \\
(\%)\end{array}$ & 0.0 & 72.9 & 79.3 & 51.6 & 46.4 & 26.8 & 37.3 & 35.3 & 17.2 & 43.4 & 14.3 & 12.0 & 41.4 & 6.1 & 15.5 & 2.6 & 51.0 \\
\hline
\end{tabular}

V (Venom), A (Antivenin), PEF (Pooled Ethylacetate Fraction), CEAE (Crude Ethylacetate Extract), FA (Fatty acids released) 
Table-3. In Vivo Antivenom Activities of PHF3 and PEF1 on Envenomed Albino Rats

\begin{tabular}{l|l|l|l|l|l|l|l}
\hline Group & Treatment & $\begin{array}{l}\text { Extract } \\
(\mathbf{m g} / \mathbf{k g} \\
\mathbf{b . w .})\end{array}$ & $\begin{array}{l}\text { Venom } \\
(\mathbf{m g} / \mathbf{k g} \\
\mathbf{b . w .})\end{array}$ & $\begin{array}{l}\text { Standard } \\
\text { Antivenin } \\
(\mathbf{m l} / \mathbf{0 . 6 m g} \text { venom })\end{array}$ & $\begin{array}{l}\text { Survival } \\
\text { Total }\end{array}$ & $\begin{array}{l}\text { \% } \\
\text { Survival }\end{array}$ & $\begin{array}{l}\text { Mean Survival } \\
\text { Time (h) }\end{array}$ \\
\hline 1 & $1 \%$ Tween-80 (Control) $)$ & - & - & - & $5 / 5$ & 100 & $24.00 \pm 0.00^{\mathrm{b}}$ \\
\hline 2 & Venom Only & - & 0.8 & - & $0 / 5$ & 0 & $0.81 \pm 0.23^{\mathrm{a}}$ \\
\hline 3 & Venom + Antivenin & - & 0.8 & 1 & $5 / 5$ & 100 & $24.00 \pm 0.00^{\mathrm{b}}$ \\
\hline 4 & Venom + PHF3 & 20 & 0.8 & - & $5 / 5$ & 100 & $24.00 \pm 0.00^{\mathrm{b}}$ \\
\hline 5 & Venom + PEF1 & 20 & 0.8 & - & $5 / 5$ & 100 & $24.00 \pm 0.00^{\mathrm{b}}$ \\
\hline
\end{tabular}

Mean survival times are presented as Mean $\pm \operatorname{SEM}(n=5)$.

Mean Survival Times carrying different superscripts from the negative control (group 2) are significantly $(\mathrm{P}<0.05)$ different using ANOVA and Duncan multiple range test.

Table-4. In Vitro and In Vivo Antivenom Activities of PEF1A and PEF1B Compounds

\begin{tabular}{l|l|l|l|l|l|l}
\hline Test Material & $\begin{array}{l}\text { NVPLA2 } \\
\text { Inhibition (\%) }\end{array}$ & $\begin{array}{l}\boldsymbol{\%} \text { Survival Animal } \\
\text { Sean Survival Time }\end{array}$ & $\begin{array}{l}\text { Rf Value } \\
(\mathbf{h})\end{array}$ & Weight (g) \\
\hline PEF1A & 23.9 & 0.0 & $2.42 \pm 0.49$ & - & - \\
\hline PEF1B & 89.8 & 100 & $24.00 \pm 0.00$ & 0.89 & 34.6 \\
\hline Antivenin & 72.9 & 100 & $24.00 \pm 0.00$ & - & - \\
\hline
\end{tabular}

\section{Discussion}

In this study, the active principles of $A$. indica leaf responsible for its antivenom activity were isolated and tested against the venom of $N$. nigricollis. Eleven (11) pooled hexane fractions (PHFs) and fourteen (14) pooled ethylacetate fractions (CEFs) were evaluated in vitro to neutralize the venom phospholipase $\mathrm{A}_{2}$ activity. Secondary metabolites (chemical constituents) are responsible for the neutralizing effect of plants that are in popular use against the action of snake venoms [26]. These plants are reputed to be capable of neutralizing the action of snake venom, and their antivenom activity has been related to certain chemical compounds identified in those plants [27].

In this research, all the pooled chromatographic fractions were found to have potentials to inhibit venom phospholipase $\mathrm{A}_{2}$ hydrolytic action with varying degree of efficacy. The pooled hexane fraction 3 (PHF3) and pooled ethylacetate fraction 1B (PEF1B) were effective at $1 \mathrm{mg} / \mathrm{ml}$ of the venom to inhibit 86.6 and $89.8 \%$ NVPLA2 hydrolytic action respectively. This was achieved at lower doses of the isolates as their higher doses may bestow $100 \%$ inhibition. Various plant chemical constituents with enzyme inhibiting and protein binding properties, active against snake envenomation include flavonoids, polyphenols, saponins, tannins, terpenoids, xanthenes etc. Phenolics, especially polyphenols, like some tannins bind proteins and act directly on venom components and could also competitively block the receptors [7].

PHF3 and PEF1B were recorded to prevent death in the envenomed rats $100 \%$ only at lower dose $(20 \mathrm{mg} / \mathrm{kg}$ b.w.). Of all the plant compounds reported against snake envenomation, the mechanism of action was somehow similar. Some of the plant constituents like coumarin, polyphenols, flavonoids, cinnamic acid derivatives, hydroxy benzoic acid derivatives, tannins and aristolochic acid have been reported to possess protein binding and enzyme inhibiting properties [5, 28, 29]. This is due to their affinity for peptides, proteins (enzymes and other toxic components) and metal binding entities in these compounds [30, 31].

\section{Conclusion}

The limitations of serum antivenin are well known and the world is searching for an alternative for snakebite treatment. The advantages of herbal antidotes are that, they are cheap, readily available, stable at room temperature and could neutralize a wide range of venom toxins. This research has provided scientific proof on the antivenom properties of $A$. indica leaf. The compounds responsible for the antivenom activity have been shown to be present in PHF3 and PEF1B which were able to inhibit the notorious NVPLA2 and provided maximum protection to the envenomed albino rats. This lends support to the traditional use of $A$. indica leaf in the treatment of snakebites. Finally, these findings would be of importance in the area of drug development with a view to actualizing the substitution of conventional snakebite therapeutic options with effective, cheap, accessible and less allergic plantbased compounds.

\section{References}

[1] World Health Organization, 2007. Rabies and envenomings. A neglected public health issue.

[2] Isbister, G. K., 2002. "Failure of intramuscular antivenom in Red back spider envenoming." Emerg. Med., vol. 14, pp. 436-9.

[3] Sutherland, S. K., 1992. "Antivenom used in australia: Premedication, adverse reaction and the use of venom detection kits." Med. J. Aust., vol. 157, pp. 734-739.

[4] Gutierrez, J. M., Fan, H. W., Silvera, C. L., and Angulo, Y., 2009. "Stability, distribution and use of antivenoms for snakebite envenomation in Latin America: Report of a workshop." Toxicon, vol. 53, pp. 625-630.

[5] Sani, I., Umar, R. A., Hassan, S. W., and Faruq, U. Z., 2018. "Antisnake venoms and their mechanisms of action: A review." Saudi J. Med. Pharm. Sci., vol. 4, pp. 512-520. 
[6] Santhosh, M. S., Hemshekhar, M., Sunitha, K., Thushara, R. M., Jnaneshwari, S., Kemparaju, K., and Girish, K. S., 2013. "Snake venom induced local toxicities: Plant secondary metabolites as an auxiliary therapy." Mini-Rev. Med. Chem., vol. 13, pp. 106-123.

[7] Gupta, Y. K. and Peshin, S. S., 2014. "Snakebite in india: Current scenario of an old problem." Clin. Toxicol., vol. 4, pp. 1-9.

[8] Nishijima, C. M., Rodrigues, C. M., Silva, M. A., Lopes-Ferreira, M., Vilegas, W., and Hiruma-Lima, C. A., 2009. "Anti-haemorrhagic activity of four Brazilian vegetable species against Bothrops jararaca venom." Molec., vol. 14, pp. 1072-1080.

[9] Sunitha, K., Hemshekhar, M., Gaonkar, S. L., Sebastin, S. M., Suresh, K. M., Basappa, P. B. S., Kemparaju, K., Rangappa, K. S., Nanjunda, S. S., et al., 2011. "Neutralization of haemorrhagic activity of viper venoms by 1-(3-dimethylaminopropyl)-1-(4-fluorophenyl)-3-oxo-1,3-dihydroisobenzofuran-5-car bonitrile." Basic Clin. Pharmacol. Toxicol., vol. 109, pp. 292-299.

[10] Soares, A. M., Ticli, F. K., Marcussi, S., Lourenço, M. V., Januario, A. H., Sampaio, S. V., Giglio, J. R., Lomonte, B., and Pereira, P. S., 2005. "Medicinal plants with inhibitory properties against snake venoms." Curr. Med. Chem., vol. 12, pp. 2625-2641.

[11] Teixeira, C., Cury, Y., Moreira, V., Picolob, G., and Chaves, F., 2009. "Inflammation induced by Bothrops asper venom." Toxicon, vol. 54, pp. 988-997.

[12] Joseph, J. S. and Kini, R. M., 2004. "Snake venom prothrombin activators similar to blood coagulation factor Xa." Curr. Dr. Targ. Cardiovasc. Haematol. Disord., vol. 4, pp. 397-416.

[13] van Acker, S. A. B. E., van den Berg, D. J., Tromb, M. N. J. L., Griffioen, D. H., van Benekom, W. P., van der Vijgh, W. J. F., and Bast, A., 1996. "Structural aspects of antioxidant activity of flavonoids." Free Rad. Biol. Med., vol. 20, pp. 331-342.

[14] Pithayanukul, P., Leanpolcharenchai, J., and Saparpakorn, P., 2009. "Molecular docking studies and antisnake venom metalloproteinase activity of Thai mango seed kernel extract. Molec." vol. 14, pp. 3198-3213.

[15] Sani, I., Umar, R. A., Hassan, S. W., Faruq, U. Z., Abdulhamid, A., Bello, F., and Fakai, I. M., 2019. "Major enzymes from snake venoms: Mechanisms of action and pharmacological." Applications, vol. 12, pp. 396-403.

[16] Khokhar, S. and Apenten, R. K. O., 2003. "Iron binding characteristics of phenolic compounds: some tentative structure - activity relations." Food Chem., vol. 81, pp. 133-140.

[17] Haslam, E., Lilley, T. H., Cai, Y., Martin, R., and Magnolato, D., 1989. "Traditional herbal medicines-the role of polyphenols." Plan. Med., vol. 55, pp. 1-8.

[18] Karamać, M., 2007. "Fe(ii), cu(ii) and zn(ii) chelating activity of buckwheat and buckwheat groats tannin fractions." Pol. J. Food Nutr. Sci., vol. 57, pp. 357-362.

[19] Aboubakar, O. B. F., Bella, N. M. T., Ngo lemba, T. E., Bilanda, D. C., and Dimo, T., 2012. "Antihypertensive activity of jateorhiza meacrantha (menispermaceae) aqueous extract on ethanol-induced hypertension in wister albino rats." Intern. J. Pharm. Pharmac. Sci., vol. 4, Available: https://innovareacademics.in/journal/ijpps/Vol4Issue2/3409.pdf

[20] AUCC, 2009. Guide to the use and care of experimental animals. Animal use and Care Committee. Vom, Nigeria: National Veterinary Research Institute. p. 1.

[21] Goswami, P. K., Samant, M., and Srivastava, R. S., 2014. "Snake venom, anti-snake venom and potential of snake venom." Inter. J. Pharm. Pharmec. Sci., vol. 6, pp. 4-7. Available: https://innovareacademics.in/journal/ijpps/Vol6Issue5/9275.pdf

[22] Razi, M. T., Asad, M. H. H. B., Khan, T., Chaudhary, M. Z., Ansari, M. T., Arshad, M. A., and Najamus, S. Q., 2011. "Antihaemorrhagic (antivenom) potentials of fagonia cretica against pakistani cobra venom (naja naja karachiensis)." Nat. Prod. Res., vol. 25, pp. 1902-1907.

[23] Dupont, S., Caffin, N., Bhandari, B., and Dykes, G. A., 2006. "In Vitro Antimicrobial Activity of Australian herb extracts against food related bacteria." Food Cont., vol. 17, pp. 929-932.

[24] Tan, N. H. and Tan, C. S., 1988. "Acidimetric assay for phospholipase A2 using egg yolk suspension as substrate." Anal. Biochem., vol. 170, pp. 282-288.

[25] Yap, M. K. K., Tan, N. H., and Fung, S. Y., 2011. "Biochemical and toxinological characterization of Naja sumatrana (Equatorial spitting cobra) venom." J. Venom. Anim. Toxins incl. Trop. Dis., vol. 17, pp. 451459.

[26] Mors, W. B., Nascimento, M. C., Pereira, B. M., and Pereira, N. A., 2000. "Plant natural products active against snakebite-the molecular approach." Phytochem, vol. 55, pp. 627-642.

[27] Alam, M. I., Auddy, B., and Gomes, A., 1998. "Viper venom induced inflammation and inhibition of free radical formation by pure compound (2-hydroxy-4-methoxy benzoic acid) isolated and purified from anantamul (hemidesmus indicus r.Br.) root extract." Toxicon, vol. 36, pp. 207-215.

[28] Alam, M. I., 2014. "Inhibition of toxic effects of viper and cobra venom by indian medicinal plants." Pharmacol. Pharm., vol. 5, pp. 828-837.

[29] Gowda, T. V., 1997. Interaction of snake venom phospholipase a2 with plant isolates. In: Kini, r.M., ed., venom phospholipase a2 enzyme: Structure, function and mechanism. New York: John Wiley and Sons, Ltd., pp. 205-222.

[30] Alcaraz, M. J. and Hoult, J. R. S., 1985. "Effect of hypolaetin-8-glucoside and related flavonoids on soybean lipooxygenase and snake venom phospholipase a2." Arch. Intern. de Pharmacodyn. et de théRapie, vol. 278, pp. 4-12. 
[31] Mors, W. B., Nascimento, M. C., Bettina, M., Ruppelt, P., and Pereira, N. A., 2002. "Plant natural product active against snakebite - the molecular approach." Phytochem., vol. 55, pp. 627-642. 